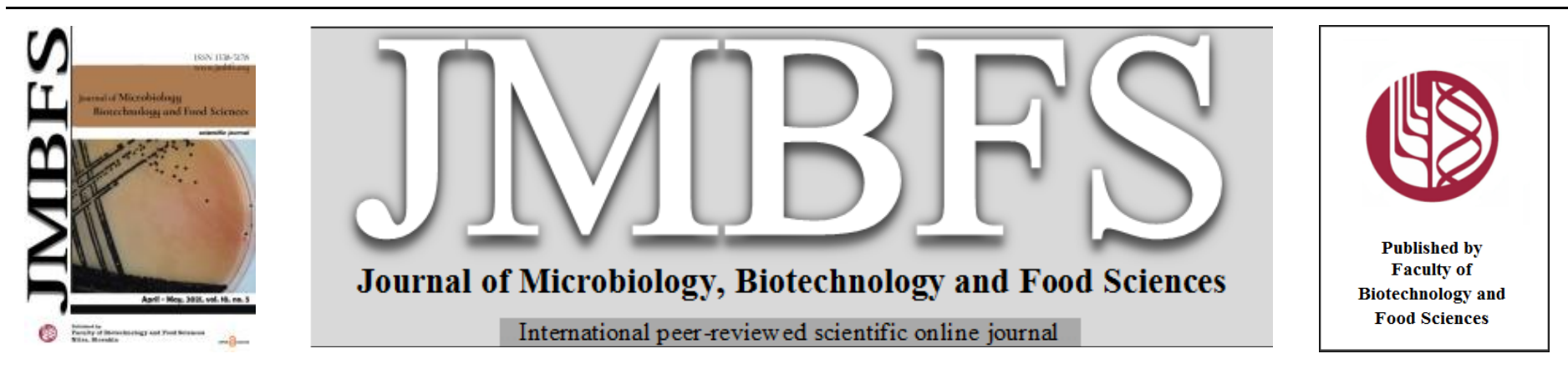

\title{
A NEW SIMPLE METHOD TO PRESERVE PHAGE - PRELIMINARY STUDY
}

\section{Anuradha Jape*}

Address(es): Dr. Mrs. Anuradha A. Jape,

Bharati Vidyapeeth (Deemed to be University), Yashwantrao Mohite College of Arts, Science and Commerce, Department of Microbiology, Pune, India Pin. 411038.

*Corresponding author: anuradha.jape@gmail.com

https://doi.org/10.15414/jmbfs. 1710

ARTICLE INFO

Received 22. 5. 2019

Revised 26. 11. 2020

Accepted 4. 12. 2020

Published 1. 4. 2021

Regular article

open $\odot$ access

\section{ABSTRACT}

The host $E$. coli and its phage were isolated from sewage water. The phage infected host, $E$ coli cells were encapsulated in alginate at specific time interval of co-cultivation, beads were stored at different temperatures. Beads were solublised to release phages and stability of released phages was evaluated by performing plaque assay at monthly interval. The number of plaque forming units increased with time of co-cultivation and by $45 \mathrm{mins}$ of phage-host co-cultivation, count raised from $10^{6}$ to $10^{8}$ pfu/ml. The infected host cells were entrapped in calcium alginate at a stage when multiple copies of mature phage are ready within host cell, and well before commencement of cell lysis.

Keywords: phage preservation, alginate, encapsulation of host infected with phage (EHIP), normal refrigeration

\section{INTRODUCTION}

Bacteriophages are the 'bacteria specific viruses', those infect host bacteria multiply inside its cytoplasm and lyse the cell to complete their life cycle. On the lysis of host, multiple copies of phage get released, that further adsorb on the fresh host cells. Phages are host specific, easy to isolate, propagate and thus are considered as promising alternatives to antibiotics (Lin et al., 2017) Biotechnological advances have expanded the range of potential applications of phages in veterinary medicine, agriculture, as preservatives in food and pharma industry. While phages are studied as potential alternative to antibiotics, methods for large scale production, handling and storage without loss of infectivity are the key factors that need to be optimized. Sensitivity of phages to various environmental factors differs readily and proves as an important impediment in maintaining their titer in acceptable range. The problem of loss in phage titer over the storage is yet not answered satisfactorily and no universal method has been reported. As free virions, phages are sensitive to various environmental factors like $\mathrm{pH}$, temperature, metal ions, etc. that may adversely affect their viability, the variation of one of these environmental factors may influence phage and change its sensitivity to the other environmental factors (Jończyk, 2011.; Ackermann et al.., 2004).

Various attempts have been made for preservation of phages since last nine decades, which include refrigeration at $4{ }^{\circ} \mathrm{C}$, deep freezing at $-80^{\circ} \mathrm{C}$ to $-196^{\circ} \mathrm{C}$, use of liquid Nitrogen (Harris, 1954; Clark and Klein, 1966; Puapermpoonsiri et al..2009; Tovkach et al., 2012), storage as glycerol stock (Clark, 1962), spray drying (Prouty, 1953; Leung et al., 2017), etc. However, each of these methods met with serious limitations and was far from being universal method. It has been reported that diluted lysates are more vulnerable to low temperature, while higher titers of phages tend to produce aggregates on storage resulting in reduced infectivity (Serwer et al., 2007). Freeze-drying (Engel et al., 1974) is a commonly tried method for long term preservation of phages; however, some phages and bacteriophage hosts are vulnerable to freezing. Coupled with lyophilisation, addition of adjuvants and stabilizers like $0.8 \mathrm{M}$ trehalose, $0.8 \mathrm{M}$ sucrose, $15 \%$ glycerol or $11 \%$ skim milk to phage lysate were reported (González et al., 2018). Staphylococcal phages showed stability at $-80^{\circ} \mathrm{C}$ to $-196^{\circ} \mathrm{C}$ for period more than 24 months of storage, irrespective of stabilizer used (González et al. 2018). Phage suspended in glycerol stock lost viability and the titer dropped to $71 \%$ at $-20^{\circ} \mathrm{C}$ and 45 to $100 \%$ at $-80^{\circ} \mathrm{C}$ (Rehman et al., 2018). Refrigeration at $4^{\circ} \mathrm{C}$ was found to be most suitable for long storage of lambda phages (Jepson and March, 2004), T4, T5, T7 tailed phages (Ackermann et al., 2004), whereas lipid containing phages, MS2 phages lost viability on storage at $4^{\circ} \mathrm{C}$. Unlike above methods those attempted storage of free virions or lysate, Golec et al. (2011) described a method for freezing freshly infected host bacteria. Mature bacteriophages can be recovered from the hos bacteria after thawing of frozen infected cells. The effect of freezing and repeated freeze thaw cycles varies from phage to phage, and also relies on_sensitivity of host bacteria to deep-freezing and to storage media. In lieu of reliable storage methods, preservation of E. coli phages in the form of DNA in freshly infected cells was reported superior. However, storage of phage using common laboratory strain of $E$. coli showed poor recovery of phage after melting the frozen infected cells (Golec et al., 2011). Storage of phage in infected Staphylococcus cells did not provide enhanced protection compared with naked phages (Golec $\boldsymbol{e t}$ al.., 2011; González et al ., 2018). Thus, storing phage as DNA in an infected host does not make a universal method and depends on the sensitivity of bacterial host to freezing.

This paper describes an alternative way of phage storage at normal refrigeration rather than the deep freezer. A simple method (referred as AAJ's AnuKul method) is described to preserve phage using alginate encapsulation of the infected host, E. coli. The infected host cells at an appropriate stage of phage development were encapsulated and stored at normal refrigeration. The host infected with phage was incubated at $37^{\circ} \mathrm{C}$ for different time intervals $(10$ mins60 mins) and then were encapsulated in alginate. The objective was to preserve host cells that enclose phage propagules, therefore host cells were encapsulated at different time intervals before they undergo lysis and release mature phages. This method (AAJ's AnuKul method for bacteriophage preservation) describes preservation of phage infected host cell by encapsulation, storage at simple refrigeration temperature and demonstrates a high titer after a yearlong storage.

\section{MATERIAL AND METHODS}

\section{Bacterial host, bacteriophage isolation and propagation}

The host E. coli and its phage were isolated from water of MulaMutha river (Pune). Water samples were taken from the site where the sewage water is discharged into the river bed. E. coli present in water sample was isolated and purified by repeated single colony transfer method using differential and selective media i.e. MacConkey's Agar and EMB agar. Characterization of the isolated colonies was carried out using standard biochemical tests (Cruickshank1975). The stock culture of E. coli (labcode aajymc09) was maintained under refrigeration temperature on nutrient agar slant and as beads, encapsulated in calcium alginate. The phage for the isolated host $E$. coli aajymc09 was obtained from the same water sample using enrichment method followed by isolation, dilution and baiting. 


\section{Pretreatment of sewage}

The sewage water was filtered through Whatmann No.1 paper disks to remove suspended material. Chloroform (1:10) was added to the filtered sewage and mixed thoroughly for 10 minutes. The treated water sample was centrifuged (5000 rpm for 20 minutes) and supernatant was transferred to sterile tubes. To remove residual chloroform the tubes were kept in waterbath at $37^{\circ} \mathrm{C}$ for 10 minutes.

\section{Co-cultivation for phage enrichment}

E. coli (18-hour old culture with cell density of $3 \times 10^{6}$ ) was co-cultivated with phage suspension $(1: 1)$ at $37^{\circ} \mathrm{C}$ for $18 \mathrm{hrs}$. Lysate was prepared by (1:10) chloroform treatment and centrifugation. For further enrichment, host and fresh phage suspension mixture was grown in phage broth (Phage broth contains tryptone $1.0 \mathrm{~g} \%, \mathrm{NaCl} 0.8 \mathrm{~g} \%$, Glucose $1.0 \mathrm{~g} \%, \mathrm{pH} 7.2$ ). Chloroform was then added and mixture was agitated for 10 minutes followed by centrifugation for 15 minutes at 7000rpm. Drops of lysate were placed on freshly lawned host on MacConkeys agar. Formation of clear zones was observed to confirm presence of specific phage for E. coli aajymc09.The enriched phage lysate was used for further experiments.

\section{Plaque assay}

The plaque assay was performed and phage titer was calculated using doublelayer technique with MacConkey agar as base agar and seed agar containing Bacto Tryptone. Aliquots $(0.1 \mathrm{ml})$ of 18-hour old host E. coli cultures $\left(2 \times 10^{6} \mathrm{cfu} / \mathrm{ml}\right)$ were mixed with $0.1 \mathrm{ml}$ of several dilutions of phage suspensions (prepared in phage broth) and then incubated at $37^{\circ} \mathrm{C}$. The aliquot of $0.5 \mathrm{ml}$ of the mixture was added to $4.5 \mathrm{ml}$ of molten soft agar $(0.7 \% \mathrm{w} / \mathrm{v})$. This mixture was poured onto base media-MacConkey agar and after solidification plates were incubated for $18 \mathrm{hrs} .-24 \mathrm{hrs}$. at $37^{\circ} \mathrm{C}$. Mature bacteriophages get released upon lysis of infected bacteria and form plaques. The dilutions showing countable plaques (30-300 plaques per plate) were considered for determining the phage titers of the lysate. The assay was performed in triplicate and results were expressed as $\mathrm{pfu} / \mathrm{ml}$. The presence of distinct plaques indicated that lytic bacteriophages have been successfully amplified, separated and grown.

\section{Phage preservation by encapsulation of infected host}

Co-cultivated phage-host mixture was incubated at $37^{\circ} \mathrm{C}$ for various time intervals (10mins, 20mins, 30mins, $45 \mathrm{mins}, 60 \mathrm{mins}$ ). At every time interval 0.5 $\mathrm{ml}$ of host-phage suspension was mixed with $4.5 \mathrm{ml}$ of sodium alginate $1.5 \%$ (w/v) slurry. The aliquots of sodium alginate mixture were dropped into chilled $0.1 \mathrm{M} \mathrm{CaCl}_{2}$ solution with continuous stirring. Capsules with an average diameter size of 2-3 mm were obtained. Alginate capsules were kept in this solution for $30 \mathrm{mins}$ at $10^{\circ} \mathrm{C}$ and then washed four times with sterile $\mathrm{D} / \mathrm{W}$ and stored under refrigeration. The alginate capsules enclose the host cells that are infected with its phage.

\section{Viability of phage infected host cells in alginate capsules}

Stability of phages during alginate encapsulation of infected host cells and subsequent storage at low temperature i.e. $4^{\circ} \mathrm{C}$ to $10^{\circ} \mathrm{C}$ was checked. The phage titer was calculated after $24 \mathrm{hrs}$ of encapsulation and at one-month interval for 12 months. To release loaded phages, alginate beads were incubated at $37^{\circ} \mathrm{C}$ for 60 minutes in phosphate buffer saline $\mathrm{pH} 7$.4. Titer was calculated as Titer $=$ Plaque $\times$ Dilution Factor/ Volume of phage plated $(\mathrm{ml})$. The data on $\mathrm{pfu} / \mathrm{ml}$ for EHIP beads stored at low temperature was assayed in triplicate at monthly interval and was analysed using one-way ANOVA and further Dunnetts multiple test at $\mathrm{p}=$ 0.05(Graph1)

\section{RESULTS AND DISCUSSION}

\section{Bacterial host, bacteriophage isolation}

E. coli was isolated from river water and characterized by its growth and color reaction on culture media MacConkey agar, EMB agar and results of biochemical tests. The phage specific to the host E. coli (isolate aajymc09) was obtained from the same water sample by baiting method. The phage preparation was spot inoculated on MacConkey agar surfaces seeded with host. Clear zones were produced due to lysis of host cells at phage-host contact sites, after incubation at $37^{\circ} \mathrm{C}$. The phage was extracted from the plaque and purified by repeated baiting. The host cells encapsulated in alginate showed no growth but remained viable when stored at $6^{\circ} \mathrm{C}$.

\section{Plaque assay}

The phage was purified and enriched by subsequent baiting. The supernatant (crude lysate) usually had a titer of average $27 \times 10^{6}$ to $38 \times 10^{6} \mathrm{pfu} / \mathrm{ml}$.

\section{Phage preservation by encapsulation of infected host}

Low temperature preservation techniques are widely used to maintain the phage stocks (Sharon et al., 2005; Fortier and Moineau, 2009). In the present study, the phage lysate stored as glycerol stock at low temperature (at $4{ }^{\circ} \mathrm{C}$ and $-20^{\circ} \mathrm{C}$ ) lost viability and could not be recovered after 6 months. Similar results describing loss of phage viability at low temperature storage were reported earlier by various researchers. Olson et al. (2004) reported that addition of 5-10\% glycerol to the phage suspension supported viability and retained infectivity of phage upto 30 days at $-20^{\circ} \mathrm{C}$ and $-70^{\circ} \mathrm{C}$. Reduction in stability of Staphylococcus bacteriophages like phiIPLAC1C, phiIPLA-RODI and phiIPLA35 by about $1-3 \log$ units on storage at $4{ }^{\circ} \mathrm{C}$ was reported by Gonzalez et al , (2018). T3 coliphage was relatively stable when stored either at temperatures ranging from 21 to $37^{\circ} \mathrm{C}$ or in the frozen state at $-20^{\circ} \mathrm{C}$, there was a $2-\log \operatorname{loss}$ in infectivity when stored for 72 days at $4^{\circ} \mathrm{C}$ (Warren and Hatch, 1969). Storage of tailed phages at $4^{\circ} \mathrm{C}$ alone is dangerous and must be backed up by deep freezing or lyophilization (Ackermann et al., 2004). Every method for phage storage has its merits and limitations and thus none of the explained methods are universally applicable for maintaining the stability for all phages.

Golec et al. (2011) demonstrated storage of phage in frozen infected cells and described it as a superior method when compared with storage of frozen lysate. The method utilized phage infected bacterial cells as a reservoir of phage DNA. The freshly infected $E$ coli, the host cells were stored at $-80^{\circ} \mathrm{C}$, those on thawing in LB medium could release active phages and served as source of mature phages. However, the common E. coli laboratory strain was reported as incompetent for phage storage and the count of infective centers decreased by three logs as an effect of freeze-thawing of infected cells. The authors (Golec et al., 2011) further described that effect of freeze-thawing on phage titer varied, and was governed by the extent of sensitivity of each host to freeze-thawing When the concern is long term preservation especially when large volumes of phage stock are to be maintained, there is a requirement of universally applicable, simple, economical method.

\section{Viability of phage infected host cells in alginate capsules}

Alginate, is regarded as a biocompatible material (Lee and Mooney, 2011) and widely used for encapsulation of microbial cells, enzymes, viruses, etc. Encapsulation of phage in alginate (Puapermpoonsiri et al., 2009; Colom et al., 2017) or other polymers like chitosan (Ma et al., 2008, 2016 Abdelsatta et al., 2009), poly-L lysine (Cui et al., 2000) has been explored to improve storage, handling, controlled release and transportation. Microencapsulation of phages with alginate/ $\mathrm{CaCO}_{3}$, as a strategy for improved phage therapy in boilers to control Salmonella infection was successfully demonstrated (Colom, 2015). The problem of phage aggregation at low temperature storage (Serwer et al ., 2007), especially in lysate with high titer is solved by encapsulation. The phiIPLARODI staphylococcal phage encapsulated in alginate retained the phage titer for 3 months at $4^{\circ} \mathrm{C}$ but showed less stability on storage at $20^{\circ} \mathrm{C}$ (Eva GonzálezMenénde, 2018). The summary of literature on phage formulation, drying, storage, encapsulation using various carriers (Malik et al., 2017) highlighted urgent need in improvising or developing a method for storage of phage. Hitherto, a number of reports claim that encapsulation of phage in alginate confer higher stability to phages. Although, encapsulation of phage in alginate beads appears promising, refrigeration at $4^{\circ} \mathrm{C}$ is a prerequisite. The present study explored benefits of encapsulation technique of phage preservation and studied effect of normal refrigeration temperature on phage stability. Host cells were infected with phage and prior to their lysis were encapsulated in alginate. The infected host cells were immobilized at specific time interval, and further stored at normal refrigeration temperature. Phages were recovered from beads and enumerated by plaque assay. Beads were solublised in Phosphate Buffer Saline pH7.4 and released phages were enumerated. Complete solublisation of bead required more than two hours of incubation in PBS. Additionally, beads were suspended in cell free supernatant of host E. coli culture grown in MacConkey broth incubated overnight at $37^{\circ} \mathrm{C}$.Beads suspended in the culture broth swell, expand and release phages. The broth serves two functions, viz. it provides required ionic environment that promotes loosening of alginate mesh and offers selective condition for survival of released $E$. coli cells (data not given).

In the beginning of the cocultivation experiment, the plaque count remains constant, this is because each phage infects one host cell and each bacterium produces single plaque. The subsequent increase in $\mathrm{pfu} / \mathrm{ml}$ occurs, as newly synthesized phages get released on lysis of host cell and infect new host cells. The cell size of actively growing host provides more surface area for phage adsorption and high proportion of protein synthesis machinery for phage multiplication (Charles, 2010). In an actively growing population of host bacteria, infected host manufactures multiple copies of phage, and considerable rise in the phage titer per unit volume may be observed.

An alginate bead holds multiple host cells and encapsulated host cell harbors multiple copies of phage, that assures increase in titer per unit volume, (Table1). 
Table 1 Effect of co cultivation time and storage of EHIP beads on $\mathrm{pfu} / \mathrm{ml}$

\begin{tabular}{|c|c|c|c|c|c|c|}
\hline $\begin{array}{l}\text { Co-cultivation time } \\
\text { (mins) }\end{array}$ & $\begin{array}{l}\text { Titer after } 24 \mathrm{hrs} \text {. of } \\
\text { encapsulation pfu/ml }\end{array}$ & $\begin{array}{c}\text { Titer after } \\
1 \text { month } \mathrm{pfu} / \mathrm{ml}\end{array}$ & $\begin{array}{c}\text { Titer after } \\
3 \text { months pfu/ml }\end{array}$ & $\begin{array}{c}\text { Titer after } \\
6 \text { months pfu/ml }\end{array}$ & $\begin{array}{c}\text { Titer after } \\
9 \text { months pfu/ml }\end{array}$ & $\begin{array}{c}\text { Titer after } \\
\text { 12month pfu/ml }\end{array}$ \\
\hline 20 & $38 \times 10^{6}(+3.77)$ & $33 \times 10^{6}\left(+\_7.45\right)$ & $36 \times 10^{6}(+3.99)$ & $37 \times 10^{6}\left(+\_1.23\right)$ & $35 \times 10^{6}\left(+\_1.66\right)$ & $33 \times 10^{6}\left(+\_2.54\right)$ \\
\hline 30 & $132 \times 10^{6}(+2.54)$ & $125 \times 10^{6}\left(+\_1.98\right)$ & $132 \times 10^{6}(+66.43)$ & $122 \times 10^{6}\left(+\_1.33\right)$ & $129 \times 10^{6}\left(+\_3.21\right)$ & $124 \times 10^{6}\left(+\_1.13\right)$ \\
\hline 45 & $142 \times 10^{8}\left(+\_13.66\right)$ & $128 \times 10^{8}\left(+\_3.72\right)$ & $137 \times 10^{8}\left(+\_1.86\right)$ & $139 \times 10^{8}\left(+\_1.36\right)$ & $122 \times 10^{8}\left(+\_5.16\right)$ & $133 \times 10^{8}\left(+\_5.44\right)$ \\
\hline 60 & $54 \times 10^{2}\left(+\_2.37\right)$ & $48 \times 10^{2}\left(+\_6.32\right)$ & $44 \times 10^{2}\left(+\_3.11\right)$ & $41 \times 10^{2}\left(+\_2.33\right)$ & $51 \times 10^{2}\left(+\_1.29\right)$ & $46 \times 10^{2}(+33.25)$ \\
\hline
\end{tabular}

Readings mean+-SD, Triplicate $(\mathrm{p}=0.005)$

Co-cultivation time has impact on titer value and thus increase in the titer could be observed consistently till the co-culture entered latent phase. The phage titer remained stable near $10^{6} \mathrm{pfu} / \mathrm{ml}$ (Table 1) initially till 40 minutes of host-phage co-cultivation and there onwards, a sudden rise in plaque count was noted. The phage titer was enriched from $38 \times 10^{6} \mathrm{pfu} / \mathrm{ml}$ to $142 \times 10^{8} \mathrm{pfu} / \mathrm{ml}$ when cocultivation was allowed for 45 minutes. The phage titer could be maintained as high as $133 \times 10^{8} \mathrm{pfu} / \mathrm{ml}$ with a variation of $12-20 \mathrm{pfu} / \mathrm{ml}$ after a yearlong storage at $6^{\circ} \mathrm{C}$. The variation in the $\mathrm{pfu} / \mathrm{ml}$ are negligible values, and such variations may be attributed to experimental errors. The time required for adsorption, the time obligatory for the bacterium to undergo rupture, and the number of new bacteriophages developing within the bacterium, all vary in each host-phage case (Abedon et al., 2001) thus the rise in titer may vary with each phage-host system. The stability of phages stored as EHIP at $6^{\circ} \mathrm{C}$ is shown in Figure1.

Graph 1. Phage preservation as EPIH

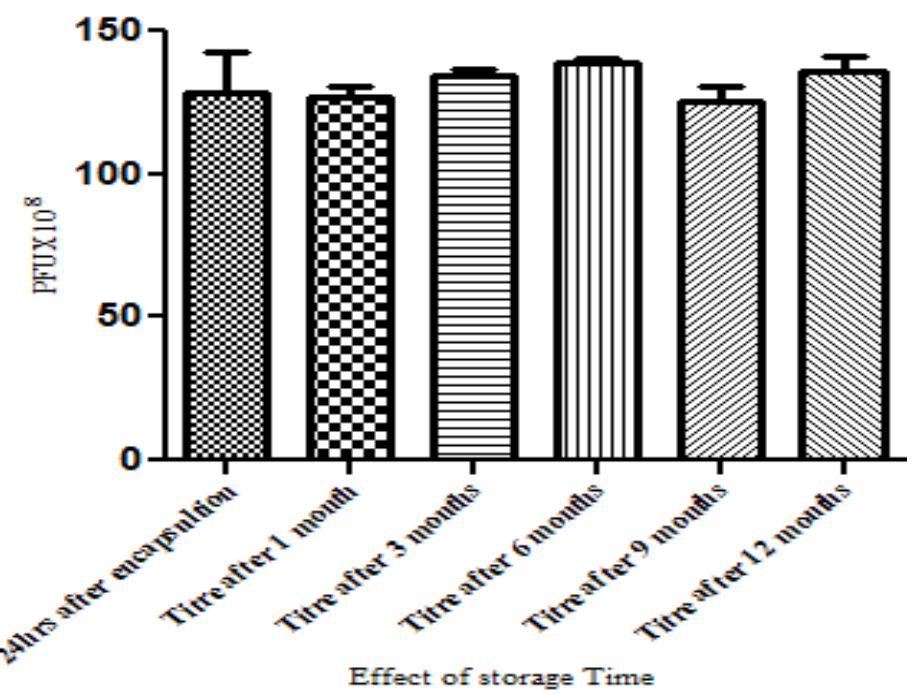

Figure 1 Stability of phage stored as EHIP at $6^{\circ} \mathrm{C}$ (Oneway ANOVA with Dunnett'sTest $\mathrm{p}=0.05$ )

Each phage type and its host bacterium may differ in the sensitivity to physica parameters. It is well known that growth of $E$. coli cell stops below $7.5^{\circ} \mathrm{C}$ temperature and in nutrient deprived conditions, storage at $4{ }^{\circ} \mathrm{C}$ shows reduction in cell size and loss of cell viability (Jones et al ., 2004). E. coli cells when stored at $6^{\circ} \mathrm{C}$ do not divide but remain as stable cultures and are not affected by temperature fluctuations. Though $4^{\circ} \mathrm{C}$ is most preferred temperature for culture preservation (Alvi et al., 2018) the cells stored at $4{ }^{\circ} \mathrm{C}$ loose viability on long storage and rate of loss of viability is accelerated by fluctuations in temperature (Jones et al,. 2004). The storage of beads at preselected low temperature helps to inhibit growth of host cell without affecting viability of host and in turn protects phage present inside the host. The storage of phage as EHIP (encapsulation of host infected with phage) at normal refrigeration that is $6^{\circ} \mathrm{C}$ is simple, does not require specialized instrumentation and thus appears to be a more promising method than cryopreservation. In this method host bacterium infected with a phage is used as a reservoir and a source of mature phages. Phages that retain viability and infectivity can be obtained on lysis of host cells in a suitable medium. It is important to understand the kinetics of phage growth for each host -phage pair and observe the latent phase of phage growth curve. The host cell infected with phage must be encapsulated at a stage when multiple copies of mature phage are ready within host cell, and well before the commencement of host cell lysis. The temperature for preservation of EHIP should be determined by conducting optimization experiments for every host -phage combination. The study can be extended for higher storage time, other coliforms and also in case of fragile phages. Encapsulation step adds on the work in maintaining phages but the better stability may compensate the drawback. This method would be suitable for preservation of master stocks of phages. It overcomes the various difficulties mentioned above and may represent a step ahead in the standardization of phage preservation procedures. The method is economical, easy and may be applicable to the freezing of sensitive phages. Owing to the simplicity this method may find a wider application in various phage-based technologies.

\section{CONCLUSION}

The results indicate that storage of E. coli phage as EHIP at normal refrigeration could be accepted as new method of coliphage preservation. The method described here is simple, easy to perform and may be described as AAJ's AnuKul method for bacteriophage preservation. The host cell infected with phage must be encapsulated at a stage when multiple copies of mature phage are ready within host cell, and well before the commencement of host cell lysis. EHIP based method (referred as AAJ's AnuKul method for bacteriophage preservation) may emerge as potential method for long term preservation of phages; though optimization study for individual host-phage pair needs to be conducted.

\section{REFERENCE}

Abdelsattar, S A., Abdelrahman F., Dawoud A., Connerton, I.F., El-Shibiny A. (2019) Encapsulation of E. coli phage ZCEC5 in chitosan-alginate beads as a delivery system in phage therapy, AMB Express 9(87). https://doi.org/10.1186/s13568-019-0810-9

Abedon, S T., Herschler, T D., David, S. (2001). Bacteriophage Latent-Period Evolution as a Response to Resource Availability. Applied And Environmental Microbiology. 67(9), 4233-4241. https://dx.doi.org 10.1128/AEM.67.9.42332001

Ackermann, H.W., Tremblay, D., Moineau, S. (2004). Long-term bacteriophage preservation. World Federation of Culture Collection Newsletter 38, 35-40 Alvi, A.I., Asif, M, Tabassum, R., Abbas Z., Rehman, S., (2018) Storage of bacteriophages at $4{ }^{\circ} \mathrm{C}$ leads to no loss in their titer after one year. Pakistan $J$. Zool., 50(6), 2395-2398, http://dx.doi.org/10.17582/journal.pjz/2018.50.6.sc8

Charles, C., Kuatsjah, E., Wu, E., Yuan, S. (2010). The Effect of Cell Size on the Burst Size of T4 Bacteriophage Infections of Escherichia coli B23. Journal of Experimental Microbiology and Immunology (JEMI).14, 85-91

Clark, WA.,Klein, A. (1966).The stability of bacteriophages in long term storage at liquid nitrogen temperatures. Cryobiology 3, 68-75

Clark, W. A .(1962).Comparison of several methods for preserving bacteriophages. ApplMicrobiol.10(5),466-471

PMCID: PMC1057894PMID: 14021544

Colom, J., Sarabia M., Otero, J. Aríñez-Soriano, P. Cortés, Maspoch D. (2017), Microencapsulation with alginate/CaCO3: a strategy for improved phage therapy. Sci Rep, 7, 41441, http://dx.doi.org/10.1038/srep41441

Cruickshank, R., Duguid, J. P., Marmion, B.P., Swain, R A. (1975). Medical Microbiology (Vol. II), 12th edn, Crurchill Living stone, New York.

Cui, J.H., Goh, J.S., Kim, P.H., Choi, S.H., Lee, B.J. (2000). Survival and stability of bifidobacteria loaded in alginate poly-l-lysine microparticles. Int $J$ Pharm. 210, 51-59.

Engel, H. W., Smith, L., Berwald, L. G. (1974). The preservation of mycobacteriophages by means of freeze drying Am. Rev. Respir. Dis. 109(5), 561-566

Fortier, L.C., Moineau, S. (2009). Phage production and maintenance of stocks, including expected stock lifetimes. Methods Mol Biol.501, 203-219 http://doi.org:10.1007/978-1-60327-164-6_19

Golec, P., Dabrowski, K., Hejnowicz, M.S., Gozdek, A., Los J.M., Wegrzyn, G., Lobocka M.B., Loś M. (2011). A reliable method for storage of tailed phages. $J$ Microbiol Methods. 84(3), 486-489 https://dx.doi.org/10.1016/j.mimet.2011.01.007

González, M. E, Fernández, L., Gutiérrez, D., Rodríguez, A., Martínez, B. García, P. (2018). Comparative analysis of different preservation techniques for the storage of Staphylococcus phages aimed for the industrial development of phage-based antimicrobial products. PLOS ONE 13(10), e0205728. https://dx.doi.org/10.1371/journal.pone.0205728

Harris, R. J.C. (1954). The preservation of viruses. Biological Applications of Freezing and Drying. Academic Press Inc., New York.

Jepson, C.D., March, J.B. (2004). Bacteriophage lambda is highly stable DNA vaccine delivery vehicle Vaccine. 22, 3413-3419.

Jończyk, E., Kłak, M., Międzybrodzki, R., Górski, A., Murthy, K., Engelhardt, R (2011). The influence of external factors on bacteriophages-review. Folia Microbiol (Praha). 56, 191-200 https://dx.doi.org/10.1007/s12223-011-0039-8 Jones, T., Gill, C.O., McMullen, L.M. (2004) The behavior of log phase Escherichia coli at temperatures that fluctuate about the minimum for growth Lett. Appl. Microbiol.39 (3). 296-300.

Lee, K.Y., Mooney, D. (2011) Alginate Properties, biomedical application, Prog. Polym. Sci.37(1),106126. 
Leung, S.S.Y., Parumasivam, T., Gao, F.G., Carter, E.A., Carrigy, N.B., Vehring, R., Finlay, W. H., Morales, S., Britton, W.J., Kutter E., (2017). Effects of storage conditions on the stability of spray dried, inhalable bacteriophage powders. Int. $J$. Pharm. 521, 141-149. http://dx.doi.org/10.1016/.ijpharm.2017.01.060

Lin, M. D., Koskella, B., Lin, H. C. (2017). Phage therapy: An alternative to antibiotics in the age of multi-drug resistance. World J. Gastrointest. Pharmacol. Ther. 8(3), 162-173. http://dx.doi.org/10.4292/wjgpt.v8.i3.162

Łobocka, M. B., Głowacka, A., Golec, P. (2018) Methods for Bacteriophage Preservation, Methods Mol Biol. 1693, 219-230. https://doi.org/10.1371/journal.pone.0205728

Ma, Y. H., Pacan, J.C., Wang, Q., Xu, Y., Huang, X., Korenevsky, A., Sabour P.M. (2008). Microencapsulation of bacteriophage felix O1 into chitosanalginate microspheres for oral delivery. Appl Environ Microbiol. 74, 4799-4805. Ma, Y.H., Islam,G. S., Wu, Y., Sabour, P. M., Chambers, J. R., Wang, Q., Shirley, X. Y. Wu., Griffiths, M. W. (2016)Temporal distribution of encapsulated bacteriophages during passage through the chick gastrointestinal tract. Poultry Science, 95(12), 2911-2920, https://doi.org/10.3382/ps/pew260

Malik,D.J., Sokolov,IJ., Vinner,G.K., Mancuso,F., Cinquerrui,S., Vladisavljevic, G.T., Clokie,M.R., Garton,N.J., Stapley.G., Kirpichnikova F.,(2017) Formulation, stabilisation and encapsulation of bacteriophage for phage therapy, Advances in Colloid and Interface Science. 249(Nov.), 100-133. https://doi.org/10.1016/j.cis.2017.05.014,

Mendez, J., Jofre, J., Lucena, F., Contreras, N., Mooijman, K., Araujo, R. (2002).Conservation of phage reference materials and water samples containing bacteriophages of enteric bacteria. J. Virol. Methods. 106, 215-24.

Olson MR, Axler RP, Hicks RE. (2004)., Effects of freezing and storage temperature on MS2 viability. J Virol Meth. 122,147-152.

Prouty,C (1953).Storage of lactic acid streptococci bacteriophage in desiccated state, observation longetivity Appl.Microbiol.1 250-251.

Puapermpoonsiri U., Spencer, J., Vander Walle C. F. (2009), A freeze-dried formulation of bacteriophage encapsulated in biodegradable microspheres. Eur $J$ Pharm Biopharm, 72, 26-33, 10.1016/j.ejpb.2008.12.001

Sharon, S.Y., Leung, T.P., Fiona, G.G., Nicholas B. C., Reinhard V., Warren H F., Sandra M., Warwick, J.B., Elizabeth, K., Hak-Kim C., Carlson, K. (2005) Appendix: Working with bacteriophages: common techniques and methodological approaches. In: Kutter E, Sulakvelidze A (eds) Bacteriophages: biology and applications. CRC Press, London.

Serwer, P., Hayes, S.J., Lieman, K., Griess, G.A. (2007). In situ fluorescence microscopy of bacteriophage aggregates. J Microsc 228(Pt 3):309-21.

Tang, Z., Huang, X. Baxi, S. Chambers, J.R., Sabour P.M., Wang Q. (2013). Whey protein improves survival and release characteristics bacteriophageFelixO1 encapsulated in alginate microspheres. Food Res Int, 52(2), 460466, http://dx.doi.org/10.1016/j.foodres.2012.12.037

Tovkach, F.I., Zhuminska, G.I., Kushkina, A. I. (2012), Long-term preservation of unstable bacteriophages of enterobacteria. Mikrobiol Z. 74(2), 60-66.

Warren, J.C., Hatch, M.T. (1969). Survival of T3 coliphage in varied extracellular environments Appl. Microbiol. 17, 256-261. 